\title{
A Comparative Study on Policies and Regulations of Private Higher Education in China and Thailand
}

\author{
Jun $\mathrm{Wu}^{1,2, *}$ \\ ${ }^{1}$ Beijing Institute of Technology, Zhuhai, Zhuhai, Guangdong, China \\ ${ }^{2}$ Bangkok Thonburi University, Bangkok, Thailand \\ *Corresponding author. Email: gdwujun@163.com
}

\begin{abstract}
This study, from the perspective of policy, adopted qualitative analysis and comparative study methods to compare the time when the private higher education policies of China and Thailand were promulgated and the four core elements of "school-running orientation", "school-running autonomy", "school-running funds" and "quality assurance". Through comparison, it can be found that the private higher education in China and Thailand develop almost at the same pace, but there are different characteristics in policy formulation. Compared with that of Thailand, China's policies on private higher education should fully take into account the diverse education market, safeguard the autonomy of private colleges and universities, refine the measures of funding support for private colleges and universities, and strengthen the quality assurance of private higher education, which is of practical significance for China to move from a big educational country to a powerful educational country.
\end{abstract}

Keywords: China, Thailand, Private higher education, Comparison of policies and regulations.

\section{INTRODUCTION}

With the proposal of China's "the Belt and Road Initiative", China and ASEAN countries have actively carried out in-depth cooperation in economy, politics, culture and education. Thailand is one of the countries with the most developed higher education in ASEAN. With a relatively perfect international higher education system, it has received extensive attention and recognition from the international community. Currently, Thailand's private colleges and universities are of a relatively large number and enrollment, accounting for almost half of Thailand's higher education.

China is a big country in higher education and is now making an effort to become a powerful country in higher education. Since the founding of the People's Republic seven decades ago, especially since the reform and opening-up four decades ago, private higher education has also developed by

*Project: 2019 Private education comprehensive or regiona research projects, Comparative Study on the Development of Private Higher Education in China and Thailand, Guangdong Private Education Association of China. Serial number: 2019GM1.2.1 leaps and bounds. Although Thailand and China are of different political systems and cultures, the rapid development of private higher education in both countries is due to the legalization of private higher education. Therefore, this paper analyzed and compared private higher education policies, which is of important reference significance for the formulation and direction of China's private higher education policies.

\section{RESEARCH METHODS}

This paper adopted the research method of grounded theory [1] and selected 14 private higher education policy texts promulgated by China and Thailand at the national level, including 5 in Thailand and 9 in China. Firstly, this paper carried out a basic description and statistical analysis of the policy texts. Then, it employed the qualitative analysis software Nvivo 11.0 PULS to code the "policy content" in three levels, and extract four comparable core categories, namely "school orientation", "school autonomy", "school funding" and "quality assurance". The specific categories mainly include 29 core contents such as school 
level, school type, property autonomy, teaching management right, student tuition, donation, school supervision and independent development". Through the analysis, this paper may reveal the attention of national policy discourse to the development of private higher education.

\section{TIME FOR POLICY PROMULGATION}

\subsection{Thailand}

Before 1969, Thailand did not have any nonstate education policy and regulation, but the idea of establishing a private higher education institution has sprouted. Until 1966, an education ministers' meeting approved the establishment of private colleges [2]. In 1969, Thailand promulgated the first private higher education law, which marked a new period for Thailand's private higher educationthe experimental period. Then, Thailand encouraged individuals to actively set up higher education schools. At this stage, 11 private higher education schools were set up successively, and 10 are still in operation, 9 of which have been upgraded to universities.

In 1979, the number of undergraduate majors in Thailand's private colleges and universities has greatly increased. To promote the development and prosperity of private higher education, support private higher education and engage private higher education in the development of Thailand's higher education, the Thai government promulgated the second Private Higher Education Law, which was revised in 1992. Then, Thailand's private higher education entered a period of rapid development, with 55 private universities successively established.

In 2003, Thailand promulgated a new Thai Private Higher Education Law to facilitate more autonomous and flexible establishment of private higher education, form an independent and free management system, ensure the academic freedom of private colleges and universities, and achieve the purpose of effective development of education. The Law was revised in 2007. At this stage, Thailand's private higher education entered a period of quality improvement and development.

\subsection{China}

According to the time and background of the promulgation of China's private higher education policies and regulations, the development of
China's private higher education can be divided into five stages [3]:

- 1st stage (1949-1977): In 1950, the Ministry of Education of the Central People's Government of China promulgated the Interim Measures for the Administration of Private Colleges and Universities. A large number of private colleges and universities underwent a stateowned transformation, dismantling, restructuring or closure, and the development of private higher education entered a stagnant period.

- 2nd stage (1978-1992): After the Third Plenary Session of the 11th CPC Central Committee in 1978, China entered a new era of reform and opening up and socialist modernization. Many social organizations and individuals actively established various educational and training institutions, and private higher education entered its infancy.

- $\quad$ 3rd stage (1993-2001): In 1993, the Interim Provisions on the Establishment of Private Colleges and Universities were promulgated, which was the first file on the legalization of private colleges and universities after the reform and opening up. Since then, with the promulgation of the regulations on running schools by social forces, private higher education has gained continuous development and entered the exploration period again.

- 4th stage (2002-2015): The Non-state Education Promotion Law of the People's Republic of China was promulgated in 2002, laying a legal foundation for nonstate education. By 2015, there were 734 private universities in China with a total of 6109013 students [4]. Private higher education has entered an expansion period.

- 5th stage (2016-present): The second amendment to the Law of the Non-state Education Promotion Law of the People's Republic of China in 2016 marks that China's private universities have officially entered a new stage featuring classified support, classified management and differentiated development. By the beginning of 2019, there were 2,663 ordinary colleges and universities nationwide, of which 750 were private colleges and universities, accounting for $28.2 \%$ of the total, and there were 6.49 million students, accounting for $22.9 \%$ of the total [5]. Private higher education has entered a stable period. 
Private higher education in China and Thailand develop almost at the same pace, but there are different characteristics and attention in policy formulation, which are mainly caused by the different political systems, social and economic development and cultural differences between the two countries. However, the private higher education policies of the two countries directly promote and guarantee the development of private higher education.

\section{TEXT ANALYSIS OF PRIVATE HIGHER EDUCATION POLICIES IN CHINA AND THAILAND}

This paper adopted Nvivo 11.0 PULS to analyze the contents of private higher education policies of the two countries and obtained 4 core codes and 765 reference nodes, namely, schoolrunning orientation (Thailand: 113, China: 202), school-running autonomy (Thailand: 108, China: 79), school-running funds (Thailand: 63, China: 51) and quality assurance (Thailand: 63, China: 29). The details are as follows.

\subsection{School-running Orientation}

School-running orientation refers to the orientation of school-running type and type of colleges and universities. Both Thailand and China have proposed clear requirements for schoolrunning orientation in their policies and regulations on private higher education. Through econometric analysis, this paper found that the two countries have almost the same school-running level, schoolrunning type, school type, school-running function and other nodes, but show different trends in the specific content description.

Thailand has clear requirements and classifications in terms of school-running orientation and school-running level. For example, the 1969 Private Colleges Law stipulates that private colleges and universities are only allowed to offer college-level courses with a length of 2-3 years to provide higher education services. The 1979 Private Higher Education Law also has clear classification and setting standards for diplomas, degrees and educational levels.

In contrast, China's regulations on schoolrunning orientation and level are relatively vague. For example, private higher education is an integral part of education and a supplement to running schools by the state. Various types of short-term vocational and technical education and on-the-job training should be mainly carried out in combination with the needs of economic construction and actual social development in the region. Private colleges and universities should adapt to the needs of economic construction and social development, make overall plans with all kinds of existing higher education, incorporate them into the national economic and social development plans, and actively guide private schools to serve social needs. In the specific schoolrunning practice, investors can only set up private colleges and universities with lower levels and similar types according to their ability.

\subsection{School-running Autonomy}

School-running autonomy is the qualification and ability to independently carry out education and teaching management as well as teaching and scientific research activities so as to realize the school-running goal. It is also an important element to enhance the legal status of private colleges and universities. The school-running autonomy of colleges and universities mainly includes the autonomy of property, the right to make plans, the right to set up specialties, the right to recruit students, the right to manage teaching, the right to set up internal institutions independently, etc.

The board of directors of private colleges and universities in Thailand has great autonomy in running schools. Based on private higher education laws and regulations, the board of directors has the power to recruit students and run schools independently. For example, with the consent of the board of directors, colleges and universities have the right to grant honorary degree certificates to qualified educators ... All these regulations have greatly enhanced the status of private institutions of higher learning, highlighted their role, promoted their development, exerted their functions, and fully reflected the autonomy of running schools (Li Xiaoying, 2013).

Compared with Thailand, China's private colleges and universities have relatively little autonomy in running schools. Although it is stipulated that private colleges and universities can set up their specialties, offer courses, select teaching materials independently, enroll student like public schools at the same level, and independently determine the scope, standards and methods of enrollment, etc., private colleges and universities generally refer to the requirements of public colleges and universities in specific practice (Shen Xinjian, 2020). 


\subsection{School-running Funds}

Fund is the basic guarantee for school running and is mainly from government funding, career income, tuition income, donations, sponsorship, loans, etc. Through econometric analysis, it can be found that the number of school-running fund nodes between the two countries is almost the same, but Thailand pays more attention to the supplement and refinement of policies.

In addition to stipulating the main income of private colleges as tuition fees, handling fees and tuition and miscellaneous fees, the government pays attention to the subsidy and support to private colleges and universities from the national level. For example, the state subsidizes private colleges and universities in proportion and sets up special working capital for loans of private colleges and universities and special working capital to improve the faculty level in private colleges and universities (Li Xiaoying, 2013).

China, in addition to self-financing by organizers, encourages governments at all levels to give financial aid and support to private colleges and universities. It formulates relevant support and subsidy policies from the national level, but lacks specific implementation measures.

\subsection{Quality Assurance}

School-running quality is the fundamental guarantee for the survival and long-term development of private higher education.

Thailand's private colleges and universities attach great importance to school-running quality and have established a strict quality assurance system, including the conditions for applying for running schools, the level of running schools, the opening of courses, the strength of faculty, the remuneration of teaching staff, the qualifications of principals, administrative agencies, asset management and other aspects. Curriculum offering and major expenditure items in private colleges and universities can only be carried out after applying to the Ministry of Education for permission. To ensure that the quality of teaching meets the standards set by the Ministry of Education, a private higher education committee has also been set up in the form of laws. The government's management of private colleges and universities involves all aspects and a set of strict quality assurance system has been established to ensure the development quality of private colleges and universities.

China's private higher education policies and regulations have few provisions on the quality assurance system for running schools, which need to be further improved. In practice, the quality assurance of private colleges and universities is implemented according to the standards of public colleges and universities. Due to the different foundations of running private colleges and universities, the quality of running private colleges and universities shows obvious polarization.

\section{DISCUSSIONS AND SUGGESTIONS}

Relevant policies of private higher education play an important role in ensuring sound development and quality improvement of private colleges and universities. With each policy innovation and evolution, private colleges and universities will be promoted to develop at different levels. Facing the internationalization in the new era, China needs to improve and optimize its policies and regulations of private colleges and universities to better play the role of system guidance.

\subsection{Private Higher Education Policies Should Fully Consider the Diverse Education Market}

China's private higher education policy pays more attention to the school-running behavior and conditions, but pays less attention to school-running orientation, school-running level, faculty and personnel training, and lacks diversified systematic planning for the development and construction of private higher education. In practice, private colleges and universities simply follow the schoolrunning form of public colleges and universities.

Private higher education is an integral part of China's higher education and is incorporated into the national economic and social development plan. China's diverse economic and social development proposes various demands for talents, and different educational groups are also differentiated. Therefore, the development of private higher education should also be diversified. When the state formulates policies and regulations on private higher education, it should encourage the diversified development of private colleges and universities, and should not adopt the same standards as those of public colleges and 
universities in school-running orientation, schoolrunning behavior, school-running level and personnel training. Thus, the special situation of private colleges and universities should be taken into account to introduce more suitable diversified development measures.

\subsection{Private Higher Education Policies Should Fully Guarantee the legal status of Private Colleges and Universities}

At first, Thailand introduced double standards for private higher education as it did for public colleges and universities. Public colleges and universities are at the top of the higher education system, while private colleges and universities are at the bottom, indicating a certain hierarchy. However, Thailand has gradually narrowed this gap through policy revision and even promoted the legal status of private colleges and universities to the same status as that of public colleges and universities.

In practice, the status of Chinese private colleges and universities in running schools has improved greatly in recent years, but there is still a huge gap with public colleges and universities in terms of social recognition, student recognition and teachers' welfare benefits. Private colleges and universities have not fully exerted their autonomy in running schools, and private higher education has not obtained the same legal status as public higher education [6]. Therefore, the policies of private higher education should focus on improving the legal status of private colleges and universities, increasing the school-running autonomy, improving the school-running quality and standardizing the school-running behavior, so as to enhance the social recognition of private colleges and universities.

\subsection{Private Higher Education Policies Should Refine the Funding Measures for Private Colleges and Universities}

In recent years, China has made a tremendous investment in education, especially in the construction of research universities. Huge funds were concentrated in a few public colleges and universities. Most private colleges and universities are the second- and third-tier colleges and universities. They are in the middle and bottom of higher education resource allocation and obtain relatively few resources for school running[7].
Private colleges and universities are an integral part of national higher education and the main base for training and building talents for the country. The state should fully consider the development of private colleges and universities in policy formulation. In light of the school-running orientation and level of private colleges and universities, it should be made clear that private colleges and universities should enjoy the same supporting policies and competition mechanisms as public colleges and universities.

\subsection{Private Higher Education Policies Should Strengthen the Guarantee of the School-running Quality of Private Colleges and Universities}

Through the econometric analysis of the private higher education policy, this paper found that China pays less attention to ensure teaching quality in its private higher education policies than Thailand. A poor quality assurance system to some extent leads to the uneven quality of private higher education. Quality assurance is crucial to contemporary private higher education, which must involve the participation of all stakeholders. First, a special quality assurance agency should be established, such as Thailand's Private Higher Education Commission; second, the responsibilities, status, member number and composition of the Committee should be clarified; third, different guarantee evaluation standards should be set up according to different school-running orientations and objectives of private colleges and universities; fourth, a perfect withdrawal mechanism for private colleges and universities should be developed.

Judging from the practice of private higher education in China for many years, quality evaluation is a vital guarantee to promote the connotation development of private higher education. The ultimate beneficiaries are students and the national education career. To this end, the state should strengthen the external quality assurance mechanism of private colleges and universities in the private higher education policy, implement normal monitoring of state data, and promote professional certification. Meanwhile, the construction of the internal quality assurance mechanism of private higher education should be strengthened (Shen Xinjian, 2020). 


\section{CONCLUSION}

Since the founding of the People's Republic seven decades ago, private higher education has gone through a long tortuous development period and entered a period of rapid development. In the future, private higher education will account for a higher and higher proportion of China's educational development. Compared with Thailand, China's private higher education policies and regulations are diversified. In this regard, expanding the school-running autonomy, ensuring the schoolrunning funds and improving the school-running quality are the priorities in the future. To sum up, Thailand's successful experience in developing private higher education is of certain reference significance for the development of China's private higher education. We should adopt its good points and avoid its shortcomings so as to gain a deeper understanding of China's own private higher education and promote the ecological and sustainable development of China's private higher education.

\section{AUTHORS' CONTRIBUTIONS}

This paper is independently completed by Jun $\mathrm{Wu}$.

\section{REFERENCES}

[1] GLASER B. Theoretical Sensitivity [M]. Mill Valley: Sociology Press, 1978:124;

[2] Li Xiaoying, Tang Minli, Trans: Guangxi Normal University Press, Thailand's Higher Education Policies and Regulations [M] 2013;

[3] Shen Xinjian: The Evolution Path of China's Private Higher Education in 70 Years of the Founding of the People's Republic [N] Social Sciences in China Press2020.01;

[4] Official website of the Ministry of Education of the People's Republic of China. http://www.moe.gov.cn/s78/A03/moe_560/jytj sj_2015/2015_qg/201610/t20161012_284508. html.

[5] Official website of the Ministry of Education of the People's Republic of China. http://www.moe.gov.cn/s78/A03/moe_560/jytj sj_2018/qg/201908/t20190812_394241.html.

[6] Ke Wei, Zhou Chao: Analysis of the Defects in Policies and Regulations of Private Higher
Education in China [J] Social Scientist, Iss.3, 2010;

[7] Xiong Qingnian: Excessive Competition is Detrimental to the Fairness of Higher Education [N]. Social Sciences Weekly. 201703-16. 